\title{
Labor and Vietnam: a Reappraisal ${ }^{1}$
}

This paper argues, from a Marxist perspective, that the shift in the Australian Labor Party’s (ALP) Vietnam war policy in favour of withdrawal was largely brought about by pressure from the Anti-Vietnam War Movement (AVWM) and changing public opinion, rather than being a response to a similar shift by the US government, as some have argued. The impact of the AVWM on Labor is often understated. This impact is indicated not just by the policy shifts, but also the anti-war rhetoric and the willingness of Federal Parliamentary Labor Party (FPLP) members to support direct action. The latter is a particular neglected aspect of commentary on Labor and Vietnam. Labor's actions here are consistent with its historic susceptibility to the influence of radical social movements, particularly when in Opposition. In this case, by making concessions to the AVWM Labor stood to gain electorally, and was better placed to control the movement.

\section{$\underline{\text { Introduction }}$}

History shows that, like the British Labour Party, the ALP can move in a radical direction in Opposition if it comes under pressure from social movements or upsurges in class struggle in the context of a radical ideological and political climate. A case in point is the "Socialist Objective", which was adopted in 1921 in the context of Labor out of power federally and a period of rising union militancy and general anticapitalist sentiment. However limited its actual content, the Objective "was a gesture towards trade union militancy”. ${ }^{2}$

By conceding to these popular left-wing pressures, Labor stood to gain potential electoral benefits. But for a reformist party, these concessions also helped to 
contain working class discontent within the capitalist system. ${ }^{3}$ Responding favourably to this extra-parliamentary pressure was highly contingent upon Labor being in Opposition, which enables unions and other party bodies to retrieve some of the control over policy exercised by the FPLP in government. Just as the British Labour Party has been more conservative in office as a result of being exposed to such influences as the public service bureaucracy and the constraints of the capitalist economy, in Opposition Labor is less subject to such pressures. Former Whitlam Government minister Jim McClelland noted the "much more radical” tone of Caucus prior to taking power in December 1972 compared to when it took office. ${ }^{4}$

\section{The Political Context}

The growth of the AVWM in the late-1960s occurred in a context of global political upheaval. Australia was not immune from this. Donald Horne argues in his book Time of Hope that the years 1966-72, "not the three Whitlam years, were the time of critical change” in Australia. Sir Zelman Cowen captured a sense of the period in his 1976 George Judah Cohen Memorial Lecture:

\footnotetext{
There are challenges to authority in many areas... People mass, march, sit in defiance of government and law, there are clashes with police...involving the massed resistance of people protesting about various political and social issues...
}

This was "one of the most turbulent periods in Australian history". ${ }^{6}$ As Whitlam's former private secretary Graham Freudenberg put it, Vietnam represented more than 
just the name of a country at war: "It is the name for an epoch". The radicalisation of the period saw Gough Whitlam, elected FPLP Leader in 1967, undergo somewhat of a political transformation. As Robert Manne puts it, Whitlam started out “as a modernising socialist of the moderate right, but by 1972 he was in the process of becoming something rather different - the symbol of hope for a new generation of the cultural left”. ${ }^{7}$

\section{Labor and the Vietnam War}

The Vietnam war was central to this radicalisation. It dominated Australian politics from the time of the first dispatch of Australian troops in 1965 through to virtual full withdrawal in 1971. Labor's attitude to Vietnam, however, changed dramatically over this period. Whereas in the early 1960s it was sympathetic to US intervention, by the time of the 1972 Federal Election it stood for complete withdrawal, for repeal of the National Service Act, and for a weaker commitment to the Australian, New Zealand and United States security treaty (ANZUS). The shift was reflected not just in policy terms, but also in the passion with which Labor MPs debated the war in parliament, the support given to draft resisters and the principle of direct action, and the election of Labor MPs onto anti-war campaign committees. The main factor in this seachange was the growth of the AVWM and the marked change in public opinion against war. $^{8}$ 


\section{$\underline{\text { Australia and Vietnam }}$}

Australia's involvement in Vietnam in part reflected a foreign policy developed at the end of World War Two which both feared Asia (particularly China), and which sought to engage US support in the region. The fall of French rule in Vietnam in 1954 raised fears, at the prompting of conservative politicians, that Australia was threatened by Communism. The pro-US regime installed after the partitioning of Vietnam in 1954 came under sustained attack from both the mainly Northern-based National Front for the Liberation of South Vietnam (NLF), and from civil conflict within, so that by the early 1960s the regime's future was threatened. This led the US to request military assistance from Australia, which was met first in the form of “advisers" in 1962. Conscription was then introduced in 1964, and troops were first dispatched in 1965. Australia remained involved in Vietnam in some form until 1972, and was a key issue, to varying degrees, in the 1966, 1969 and 1972 federal elections. ${ }^{9}$

Contrary to popular notions that Australia was dragged into the War by the US, it was an enthusiastic participant from the beginning, which reflected the strategic interests of Australian capitalism in preventing the success of a national liberation movement in the region, and in aligning itself with a world power capable of policing a global market-based order. ${ }^{10}$ 


\section{Early Labor Policy on Vietnam}

Early Labor policy largely supported US intervention. Thus while Tom Uren, from the Left faction of the FPLP, expressed opposition to the sending of Australian military “advisers” to Vietnam between 1962-63, "the great bulk of Caucus members” tacitly supported the move. ${ }^{11}$ An August 1964 meeting of Labor's Federal Executive, ${ }^{12}$ resolved to oppose not the use of Australian armed forces personnel in Vietnam per se, but rather "the lack of any formal [United Nations] agreement to cover the[ir] presence". In response to US bombing in February 1965, the ALP Right’s Kim Beazley Snr, who would later become a Whitlam Government minister, successfully moved a motion in Caucus justifying the actions on the basis that America:

insisted that its object in South Vietnam, while resisting aggression, is to achieve a peaceful settlement maintained by the presence of international peacekeeping machinery and that it would not allow the situation to be changed by terror and violence. This statement of American purpose is unexceptionable. ${ }^{13}$

When External Affairs Minister Paul Hasluck suggested in early 1965 that an antiAmerican campaign was being waged in Australia, Calwell responded by singling out the Communist Party of Australia (CPA) as the only ones guilty of that charge, and by stating emphatically that " [t]he United States must not withdraw and must not be humiliated in Asia."14 Whitlam, like Calwell, did not want America to "leave or abandon interest in the area" because she was the "only effective counterweight to Chinese influence there.”15 The strong undertones of anti-Communism in such 
statements reflected Labor's bipartisanship with the Government on the security threat posed in South-East Asia by China and the nationalist Sukarno Government in Indonesia. This, in turn, implied backing for US efforts to contain "Communism" in Asia. Indeed, Calwell affirmed Labor's bipartisan support for ANZUS, for antiCommunism, and for the defence of Australia. ${ }^{16}$ Even Jim Cairns, later to become "the most prominent opponent of the war", ${ }^{17}$ restricted himself to opposing any escalation of the conflict, conceding that withdrawal was not "feasible". ${ }^{18}$

What this reveals is that there were important characteristics common to the statements of most Labor MPs and wider party bodies: they showed caution in raising objections to the war, if not outright sympathy for it. The evidence in these early stages thus does not support Guy, who claims that the party’s position “was consistent from the start...it opposed the war firmly even at the cost of electoral support”. ${ }^{19}$ The evidence also undermines the view that Vietnam debates in the party during most of the 1960s were polarised between Cairns and Whitlam, and more widely between the Left faction and the "mainstream" of the party. ${ }^{20}$ While there were differences between individuals and factions, in general Labor was cautious in questioning the intervention. The later policy and other changes in the party's stance, as we shall see, similarly reflected a shift in attitude across the ALP, not just on the part on the Right.

The decision of the Menzies Liberal Government to dispatch Australian troops to Vietnam in May 1965 produced no fundamental change in this situation. Calwell and fellow Labor MPs opposed it largely on the basis that it was antithetical to Australia's national interests. This, as we have seen, ignored the very real strategic interests of Australian and US capitalism potentially threatened by a successful national liberation movement in South-East Asia. A more notable omission from Calwell's speech, however, was a call for the withdrawal of Australian troops. ${ }^{21}$ 


\section{Vietnam Policy in the Lead Up to the 1966 Election}

In April 1966 at the Tasmanian State ALP Conference in Launceston, Calwell promised the return of "all conscripts then serving anywhere overseas" if elected. However, it was unclear whether there would remain a role in Vietnam for regular Australian soldiers. As Hudson notes, the lead-up to the 1966 Federal Election was characterised by conflicting ALP statements on Vietnam. A Cairns speech to ALP candidates prior to the Election, which put less emphasis on the withdrawal aspect of the party's policy, caused the left wing to go "berserk. Some of them thought Jim was a traitor... The left never forgave Jim for that.” In an attempt to rectify the confusion, Calwell announced in May that a Labor Government would direct the Army, "acting with full regard to the safety and security of the Australian forces", to bring home without delay all conscripted Australian men in Vietnam. Confusion, however, reigned just as before. Three ALP politicians returning from a tour of Vietnam in July pointed to the impracticability of withdrawing conscripts but not regulars. Meanwhile, in August Victorian federal Labor MP Sam Benson was expelled from the party for publicly backing the war. Shortly after, Beazley Snr published virtually a pro-war article criticising the ALP's Vietnam stance. In early November, Calwell qualified the party's commitment to withdrawing conscripts as soon as possible, with the remaining regulars being removed after consultation with the US. In this context, Whitlam's infamous statement just prior to the Election, that a Labor government 
might "send regulars" to Vietnam, attracted more controversy than it warranted. As Freudenberg remarked, this incident "merely confirmed the appearance of disarray [on Vietnam] which the Labor Party had given throughout 1966." ${ }^{22}$

It is thus mistaken to characterise, as is commonly the case, the Vietnam debate in the ALP in the run-up to the 1966 Election as one polarised around the positions of Whitlam and Calwell. While it is certainly true that Calwell took a stronger stand against the war than Whitlam - owing partly to Calwell’s factional interests, and his intense opposition to conscription - the point is that the party lacked a clear position on withdrawal. This helps explains the ease with which Whitlam was able to further weaken the party's stance after $1967 .^{23}$

\section{$\underline{\text { Vietnam Policy Post-1966 Election }}$}

At the November 1966 Federal Election, largely a referendum on Vietnam, Labor recorded its lowest House of Representatives Two-Party Preferred Vote (TPPV) since 1949 (43.1 percent). When Whitlam defeated Jim Cairns for the leadership of the FPLP (39: 15 votes) on 8 February 1967 following the resignation of Calwell, many commentators heralded Whitlam as a non-doctrinaire moderniser who would rein in Left Wing extremists, and make the party once again electable. A committed centralist who a priori eschewed any political strategy that did not accord a major role for the Commonwealth Parliament, Whitlam believed that the prosperity associated with the post-war boom obviated the necessity for fundamental economic reform such as nationalisation (though this was also based on High Court interpretations of the 
Constitution). He sought to "modernise" the party by broadening its constituency beyond that of rank-and-file trade unionists. ${ }^{24}$

Central to Whitlam's project was the moderation of the party's Vietnam policy. Accordingly, one of his first acts as Leader was to substitute himself as ALP spokesperson on foreign affairs for Jim Cairns, and he made a concerted effort to soften Labor's policy on Vietnam, as well as avoid the issue whenever the Government raised it. In Whitlam’s own words, he set out to "de-escalate" the debate on Vietnam inside the party. In the lead up to Federal Senate elections in late-1967, Whitlam stated in a party advertisement: "Vietnam is no longer as black and white as it may have appeared last year". As a result of statements by Whitlam, including his comment that Calwell had "debauched" the Vietnam debate in 1966, Whitlam was the target of anti-war demonstrators in February $1968 .^{25}$

Yet, Whitlam was far from alone in pursuing a more moderate line on Vietnam. For instance, Federal Vice-President W.R. Colbourne issued a report urging the party to cease contesting elections on foreign political or military situations. As Langley remarked, Whitlam's efforts to moderate the policy "were generally accepted by the party." The general mood within the FPLP for a more accommodating line culminated in the adoption of a position at the August 1967 ALP National Conference $^{26}$ that made withdrawal contingent upon Allied failure to meet three conditions: (a) the cessation of US bombing; (b) recognition of the National Liberation Front as a negotiating party; and (c) a change in war strategy to "holding operations". While not Whitlam's preferred outcome - he preferred to not commit to withdrawal - it was, as Oakes put it, "one he could live with", for it was interpreted as a retreat from the policy taken to the 1966 Election. $^{27}$ 
The process of liberalisation largely continued through to 1968 until a shift in public opinion and the growth of the AVWM led to a reversal in the direction of Labor policy.

\section{The AVWM and Changes in Public Opinion}

The 30 January 1968 “Tet Offensive” by North Vietnamese forces against South Vietnamese and US Government installations precipitated a shift in Labor's attitude to Vietnam. By exposing an absence of popular support necessary for the South Vietnamese Government to retain power without the aid of US troops, the Tet Offensive also marked a general watershed in the war. ${ }^{28}$

The Offensive also had a considerable impact in Australia, where early opposition to the Vietnam War had been marginal. There was support for the Government's decision to dispatch infantry in April 1965, and for the first increase in troops in September. The first anti-Vietnam war march took place in 1964 following the introduction of conscription. Anti-conscription organisations Youth Campaign Against Conscription (YCAC) and Save Our Sons (SOS) were the first organisers of anti-war opposition. This included demonstrations outside US consulates in early 1965, and draft card burnings. Despite Labor's equivocation over withdrawal, it gained the support of anti-war activists in 1966. Because the war was clearly the election issue, Labor's defeat at that year's Election represented a devastating blow to the Movement. YCAC subsequently collapsed, and there were almost no demonstrations against the war in $1967 .{ }^{29}$ 
For the AVWM, the Offensive was an inspiration, helping to revive a movement which had atrophied following the 1966 Federal Election. However devastating was that election result, as Picot argues by "eliminating the electoral option [it] created a space for more radical politics". Thus, 1968 saw the formation of the militant Draft Resistance Movement (DRM). Although lasting as an organisation only a few months, the DRM's emphasis on militant direct action was taken up by a range of militant student groups, such as Students for a Democratic Society (SDS) at Sydney University, and the Monash University Labor Club in Melbourne. Their greater influence in the Movement manifested itself in the large, militant demonstrations that occurred from 1968 onwards. A case in point was the demonstration outside the US Consulate in Melbourne on Independence Day 1968, as reported in The Age:

For the first time in 25 years, mounted troopers last night were ordered at full canter into violent crowds in front of the U.S. Consulate-General in Commercial Road, Prahran...

The horses charged into the crowd at least a dozen times to the aid of police fighting savagely with demonstrators close to the building. ${ }^{30}$

The Independence Day demonstration outside the US consulate the following year involved clashes between 250 baton-wielding police and three thousand demonstrators. This greater militancy continued throughout 1968 and 1969, with a series of sit-ins and raids on government offices organised by and involving the above student groups. Nineteen sixty-nine also saw an increase in trade union opposition to the war. Later that year, the Australian Council of Trade Unions (ACTU) reversed its policy of not supporting industrial action that withheld the supply of war materials to 
Vietnam. These developments coincided with a shift in public opinion. For instance, in late-1968 for the first time there was less than majority support for the war (see opinion poll data referred to in Table 1$).{ }^{31}$

Table 1: "Do you think we should continue to fight in Vietnam or bring our forces back to Australia?" ${ }^{32}$

\begin{tabular}{|l|l|l|l|l|l|l|l|l|l|l|}
\hline Month/Year & $9 / 65$ & $9 / 66$ & $5 / 67$ & $10 / 68$ & $12 / 68$ & $4 / 69$ & $8 / 69$ & $10 / 69$ & $10 / 70$ & $10 / 70$ \\
\hline Continue & $56 \%$ & $61 \%$ & $62 \%$ & $54 \%$ & $49 \%$ & $48 \%$ & $40 \%$ & $39 \%$ & $43 \%$ & $42 \%$ \\
\hline Bring back & 28 & 27 & 24 & 38 & 37 & $40 *$ & 55 & 51 & 45 & $50 *$ \\
\hline Undecided & 16 & 13 & 14 & 8 & 14 & 12 & 6 & 10 & 12 & 9 \\
\hline
\end{tabular}

* "bring back now"

The Tet Offensive and the growth of the AVWM were likely factors in this shift. Media coverage of atrocities such as the massacre in the South Vietnamese village of My Lai also is likely to have caused many to question the "liberating" nature of the war. Also, by 1969 combined US and Australian casualties had surpassed those suffered in the Korean war, and in its seventh year Vietnam had now become Australia's longest conflict. ${ }^{33}$

\section{Labor and Vietnam Post-Tet Offensive}


The Tet Offensive marked a turning point in Labor's attitude to Vietnam. Henceforth, according to Beazley Jnr, both the Left and Right of the party considered Vietnam to be an electoral liability for the Government. This was reflected in Labor's adoption of a position at the 1969 Federal Conference in favour of phasing out troops over a period to be decided in consultation with the US Government. In his Federal Election campaign speech later that year, Whitlam declared: "Under Labor, there will be no Australian troops in Vietnam after June 1970." Labor’s much improved performance at the 1969 Election, where it gained 18 seats and a seven percent increase in its TPPV, reflected the war's increased importance as a political issue and its greater unpopularity amongst voters. Thus, at year's end the Gorton Liberal Government announced a phased withdrawal from Vietnam, beginning in mid-1970. ${ }^{34}$

In addition to the electoral boost, the deepening public disenchantment explains why Labor’s Vietnam policy post-1969 Election went in the opposite direction to that post-1966. Labor MPs were increasingly prominent in acts of civil disobedience. Shortly after the Election, for example, Jim Cairns and other federal Left MPs, Gordon Bryant and Moss Cass, publicly burned the National Service cards of draft resisters. This was a marked turnaround from conscription's introduction in 1964 when "[n]o-one in the ALP...seemed prepared to attack the very legitimacy of the scheme". Jim Cavanagh would go even further in 1971 by asking in relation to draft-resisters: "What alternative is left to our youth but to rebel? Are they not following the tradition set by their forefathers? Are they not great examples of Australia's heroic manhood?”35

The actions of Cairns, Bryant and Cass partly reflected the unambiguous evidence of growing international anti-war sentiment, with 250000 protestors marching on Washington the same day. However, it also signified the growing 
strength of the Left in the ALP. Whereas Whitlam and others might once have publicly admonished such unlawful activities, they were now silent. Whitlam's authority in the party room had deteriorated since 1967. The shift against Whitlam had been evident from as early as 1968 when he defeated Jim Cairns in a leadership contest by a mere six votes (38: 32). The margin of the victory shocked Whitlam, who, according to McMullin, proceeded henceforth more cautiously in an effort to avoid confrontation. This was a significant development on the part of the "crash or crash through” leader. Whitlam's position deteriorated further post-1969 Election when two Left MPs were elected to the new Shadow Cabinet, while three "unswerving supporters” of Whitlam failed to gain re-election. Similarly, Colin Jamieson, ally of Whitlam arch-rival "Joe” Chamberlain, ousted Whitlam stalwart Kim Beazley Snr from the Federal Executive a year later. By this stage, the Left, in terms of numbers, controlled both the Federal Conference and the Federal Executive, the party's two most sovereign bodies. Another indicator of the Left's strength was Jim Cairns' garnering in the first Caucus ballot post-1972 Election of the third highest number of votes behind only Whitlam and Deputy Leader Barnard. ${ }^{36}$

In this changed factional context, a shift to the left by Whitlam served his leadership interests. Government MP Stephen Calder ventured that Whitlam, who "started his political life as a moderate or even a liberal, is now leaning further to the left" in order to retain "the leadership of the new look left wing Labor Party”. Such statements plainly had partisan motivations. Yet, there is other evidence of Whitlam's apparent radicalisation. For instance, he informed Caucus in 1970 that he intended to advise balloted men in his electorate to disobey orders to serve in Vietnam. His comments stunned the Government, but also many Labor MPs who were displeased with Whitlam for condoning registering with the Act at all! Whitlam clarified that he 
was not advocating mutiny. Nevertheless, as Saunders argued it was "impossible to imagine Whitlam making these statements...prior to the 1969 elections." ${ }^{37}$

However, Whitlam's actions throughout this period reflected less a personal radicalisation than a keen sense of Realpolitik, for Whitlam was a pragmatic politician with an astute reading of the political situation. Laurie Oakes commented on Whitlam's campaign during the Werriwa by-election in 1952: "He would masquerade as a left-winger at Bundeena and Helensburgh...but he'd be a moderate member of the middle-class in more select areas". This pragmatism was on show in the later years of his political career. In the aftermath of the 1975 Dismissal when Labor was in retreat from many of its policies in office, Whitlam argued that Labor's historic aspirations for social reform would need to be kept in check as a result of the lower economic growth that followed the collapse of the post-war boom. For instance, Whitlam told the party's 1977 Conference that while the post-war boom economy provided the wherewithal to pledge social reform through a larger public sector: “The economy in the seventies is a different story... We have to live with that. We have to moderate our social goals both for the sake of the economy and for the sake of the programs themselves...”. 38

Re-orienting his statements in a more leftward direction during the heady political climate surrounding the AVWM served the leadership interests of Whitlam. However, by attracting the support of radicalising elements in society this leftward tack also suited Labor's electoral interests. Whitlam's strategy, of course, was not without its risks. As The Age put it, his “dilemma” revolved around how to appease the Left without damaging his "Prime Ministerial prospects” and “political stature”. Yet, while Whitlam's gestures to the Left potentially alienated Age editorialists, it is arguable that these political manoeuvres were more in tune with the wider political 
mood. The mass Moratorium protests beginning in 1970 posed a further test of this balancing act. ${ }^{39}$

\section{Labor and the Vietnam Moratorium Campaign}

The AVWM peaked in Australia with the Vietnam Moratorium Campaign (VMC) (modelled on demonstrations in the US the previous year) beginning in May 1970. Labor's attitude to the VMC is sometimes depicted as hostile or suspicious. For instance, Catley writes that Labor’s “support for the Moratorium was conditional”, and that it looked "for an escape route" given fears of violence and negative electoral repercussions. Yet, this interpretation is open to challenge. While it might be true, as Saunders argues, that the ALP's practical assistance to the Moratorium was minimal, it is misleading to say that Labor parliamentarians, officials, and Branches either "did not support [it] or gave only cautious support”. ${ }^{40}$

For example, the ALP Federal Executive earlier that year had called upon the FPLP to lead an anti-war campaign. Twelve federal Labor senators attended the meeting at which the Moratorium was initiated and a national coordinating committee and provisional State convenors were elected. Furthermore, all but thirteen of the 87 FPLP members endorsed the VMC in writing. Federal or State Labor MPs were elected to Moratorium Committees in all States except New South Wales, and Jim Cairns was elected Chairman of the Victorian Moratorium Committee. ${ }^{41}$ So seriously did the FPLP treat the VMC that it moved, albeit unsuccessfully, for the Parliament to commence sitting on Fridays from 15 May rather than 8 May (the day of the first Moratorium march) because, as Barnard put it, "[s]ome honourable members on this 
side of the House have made very important commitments for $8^{\text {th }}$ May". Labor MPs even sported Moratorium badges in Federal Parliament. Along with Calwell, Lionel Murphy and Jim Cairns, Whitlam addressed the 6 May Canberra Moratorium protest outside Parliament House - possibly the first occasion on which Whitlam spoke at an anti-Vietnam war protest rally. ${ }^{42}$ During parliamentary debate in April 1970, the Government pressured Whitlam to denounce the VMC and any violence it might cause. He refused: "In fact I shall address a meeting organised by the Canberra Vietnam Moratorium Committee.” Whereas in the past Whitlam had opposed the use of extra-parliamentary means to induce political change, he now rejected the notion that politics was solely about "voting at parliamentary elections”: "Demonstrations, peaceful demonstrations, are as legitimate and as necessary a part of the democratic processes as elections themselves." Thus Murphy's claim that "Whitlam distanced [himself]...from the first Moratorium", is not quite accurate. The above statements appeared to contradict Whitlam's pronouncement the previous year that foreign policy under a Labor Government would not be determined by petitions and mass meetings. This shift in Whitlam's thinking, or at least in his public statements, is often ignored. While Whitlam had, unlike many of his Caucus colleagues, not given written endorsement to the VMC, he insisted that this said "nothing one way or the other about my attitude towards my support for the aims of the moratorium campaign". 43 In the event, the Moratorium was an astounding success. The 8 May Melbourne demonstration was, according to The Australian, "the biggest anti-war rally in Australia's history." One historian recorded that in Melbourne:

a crowd estimated at 100000 strong had flooded into the city centre, closing all commercial activity and occupying the streets... In Sydney over 45000 marched through the city centre. 
In small country towns and remote mining areas there were marches and strikes ... [T]he evidence of a rapid change in public opinion was now quite evident. ${ }^{44}$

Labor was buoyed by the protests. Mungo MacCallum, observing the triumphal tone of Moratorium-related questions that Labor put to the Government in Federal Parliament the following day, had seldom seen "a smugger lot of next-of-kin than the Labor members assembled in the House of Representatives yesterday". ${ }^{4}$

The effects of the mass movement were also discernible in some Labor MPs' willingness to de-prioritise parliamentary politics. We have already seen the newfound willingness of Whitlam to advocate direct action. This was even more true of Cairns. Witness his speech to the September 1970 Melbourne Moratorium:

In order to govern yourself you have to exercise power wherever power is, and Parliament is not the only place where there is power. Power also exists in schools, in universities, in factories, in Government departments, in banks and everywhere else... We have won our democracy by breaking laws, by campaigning in the streets. We have won our democracy by cutting off the heads of kings. ${ }^{46}$

Cairns was not alone in stressing the importance of direct action. Jim Cavanagh had earlier argued in effect that the withdrawal of Australian troops from Vietnam was not contingent on the election of a Labor Government, but could be achieved through mass demonstrations. One month after the May Moratorium protests, Federal President Senator Keeffe promised the annual Victorian State ALP Conference that: 
"If the forces of darkness overcome us and a dictatorship is established, then it is our party that will supply the revolution". ${ }^{47}$

The willingness of Labor figures to support protests and civil disobedience is a particularly neglected aspect of commentary on the party’s response to Vietnam. There had been little, if any, direct action content in the rhetoric of federal Labor MPs leading up to this period. Jim Cairns, for example, was not always a committed direct actionist. His Living With Asia (1965), which assembled the themes on which Cairns had spoken since the 1940s, had almost nothing to say on the subject of direct action, conceding only that there was "often a strong practical case" for it. Whatever parliament's flaws as a vehicle of social change, he argued, "it is by far the best we have". One draft-resister, Hamel-Green, recalled that Jim Cairns initially "was not in favour of civil disobedience", but that he had been persuaded by the time of the Moratorium. Community-based change figured more prominently in Cairns’ politics only when collective action became more widespread. ${ }^{48}$ Other Labor MPs are similarly likely to have become more sympathetic to direct action as it increased in popularity.

This lends support to the point made earlier that, while there were differences between the ALP Left and Right on Vietnam in the initial stages of Australia's involvement, the latter stages of the war witnessed a shift in attitude across the party. Saunders rightly mentions the varied response of Labor to the AVWM and the Moratorium, with only the Victorian branch declaring its wholehearted support for smaller September 1970 Moratorium demonstrations. It is also undeniable that there were always divisions within Labor over Vietnam. ${ }^{49}$ The very nature of the ALP, with its factional system and its representation of diverse social forces, means that conflict within the party over contentious political issues is inevitable. 
Nonetheless, Saunders overstates the case when he says that the "ALP's new enthusiasm for the activities of the peace movement had hardly developed when it began to dissipate". For instance, the Federal Executive unanimously endorsed the September Moratoriums, and called for joint supporting action between the ALP and the ACTU. This was fulfilled in the Right-dominated New South Wales at least, where the Labor Council and the ALP staged a joint rally at Sydney Town Hall addressed by, among others, Whitlam and Cairns. Recently-retired ALP Federal President Senator Keeffe was questioned by police at the Canberra Moratorium protest for informing activists of his intention to continue advising young men against registering for national service. Other ALP figures to address protestors during Canberra Moratorium activities included Whitlam, Tom Uren, Senator Wheeldon and Gordon Bryant. Among the "first ranks of marchers" at the 50000 strong protest in Melbourne were Federal President-elect Tom Burns and Federal Secretary Mick Young. ${ }^{50}$

It seems beyond doubt that across the board the party was impacted on by the radical shift in opinion against the war. The Left's cautious response to anti-war protests, and the reluctance to call for troop withdrawals in earlier years, gave way to high profile participation in anti-war demonstrations and support for sometimes illegal activities. The Right, meanwhile became more willing to acknowledge the need for direct action, and their rhetoric became increasingly anti-war, in contrast to earlier pro-war statements by those such as Kim Beazley Senior (see footnote 22). One cannot conceive, for example, of any high figure in the party in 1969, let alone 1972, uttering Calwell's 1965 statement that the US must not suffer the ignominy of forced withdrawal, because by that time growing numbers of people wanted the US to suffer that very humiliation. Whitlam went from being a target of anti-war demonstrators to 
giving speeches to protestors, to advocating direct action, and to urging young men to resist the draft. As Langley has argued, Whitlam’s 1969 pledge to withdraw was made after "the groundswell of opposition to the war became apparent". Similarly, Lance Barnard, had in 1967, called upon the party to take a "hard look" at its defence and foreign policies in light of his observation from South Vietnam of large-scale troop incursions from the North. However, in 1970 he commented how proud he was that Labor was moving to change the date of Federal Parliament's sitting so that ALP MPs could attend the Moratorium demonstration (see footnote 42). The evidence points to a Right Wing less openly hostile to the AVWM. As Saunders argues: "During the later years of the war...right-wing spokesmen for the party rarely criticised the peace movement for the involvement of communists within it”. ${ }^{51}$

\section{$\underline{\text { Labor and Direct Action }}$}

Despite it being a recent development, there were sound strategic reasons for Labor leaders to encourage grassroots activism. As Cliff and Gluckstein argued in the British context, Labor leaders are capable at times of endorsing extra-parliamentary activity because it is not the commitment to parliamentarism that is the sine qua non of Labor in Opposition, but rather the role of mediating between classes. If they "feel that parliamentarism is actually an obstacle to the process of mediation it may be put aside". Murphy notes that the AVWM was "a social movement which for a time dwarfed parliamentary politics". Labor leaders, in adopting radical rhetoric and shifting their policy positions, may have hoped to benefit electorally from this movement, but also to defend constitutional politics in the longer-term. After all, it 
was partly Labor's move to the right on Vietnam post-1966 Election which "fuelled the radicalisation of the [AVWM] and took its centre further beyond Labor's concerns, to the satisfaction of many radicals". Gaffney has argued that "Labor's success in retaining working class support and containing the worker within the system could not have been achieved if the ALP had been wholly unresponsive to working class pressure, and in some points in fact antagonistic to the capitalist system eg, conscription today." 52

Jim Cairns cited evidence of the electoral benefits arising from Labor’s endorsement of the AVWM: "The cautious and limited identification of many Labor and union leaders with the anti-Vietnam war movement...did something to help elect a Labor government in 1972". There is also evidence of Labor seeking to contain the movement. In relation to Cairns' role at the second Moratorium protest in Melbourne in September 1970, the Melbourne Sun reported that, in preventing marchers from “causing chaos”, he had succeeded where the police had failed. Cairns' biographer Paul Strangio writes that his subject wished to "harness the energy of the student radical movement, while restraining some of its more intemperate and doctrinaire elements." $^{53}$

There were no doubt differences in the extent to which Labor figures were prepared to be involved with the AVWM, partly determined by factional position. However, both the Labor Left and Right could accommodate direct action, and could even assert on occasions such as the Whitlam parliamentary speech in 1969 cited above (see footnote 43) that it carried as much weight as parliamentary work. What all Labor figures appeared to agree on was that direct action could achieve only limited results when unaccompanied by a parliamentary strategy. For example, even Ken Carr from the Socialist Left faction in Victoria suggested that Labor needed to 
become an "effective channel” for direct action: "For the Labor Party to do this, it will have to orient its activities both towards pressure grouping and parliamentary action.”54

\section{Changes to Labor Policy}

The effect of the AVWM on the ALP went beyond rhetoric to the level of policy. There was further evidence of this post-Moratorium. For example, the 1969 Federal ALP Conference undertook to repeal the National Service Act, but its successor in 1971 went further by pledging to "annul its penal consequences". Conference also endorsed the Victorian Branch's preselection of draft-resister Barry Johnson, then on the run from police, for the Victorian seat of Hotham in the 1972 Federal Election. Furthermore, the party downgraded its support for the ANZUS Treaty so that for the first time since 1957 it was no longer "of crucial importance". This can be seen partly as a sop to the Left since Cairns had earlier nominated an "end to the principle that the US alliance is crucial" as one likely result of Left control of the ALP leadership. The change represented an appreciable retreat from Whitlam's position in 1967, when he argued that "the overriding, the paramount, statement on our foreign policy in the Australian Labor Party platform is that the American alliance is crucial." This shift must be set in the context of the growing disquiet with US imperialism and Australia's complicity in its crimes. ${ }^{55}$

Among other decisions of note taken at the 1971 Federal Conference was the passage of a motion, initiated by the Right's John Ducker, expressing support for the “principle” of the Moratorium demonstrations. Although this support was qualified 
with expectations that the protests be “executed on a peaceful basis”, and that members co-operated “in Vietnam Moratorium activities on a State and locality basis, under the control of the State branches”, the very fact that such a conservative member of the party would move a motion of this kind illustrates the extent of the impact of the radicalisation surrounding the AVWM. Also, Conference voted down a resolution supporting the abolishment of the Chifley Labor Government's brainchild, the Australian Security Intelligence Organisation (ASIO), but only after Conference Chairman Tom Burns cast his vote to break a 22-all deadlock. The resentment towards ASIO reflected its role in persecuting anti-war activists. ${ }^{56}$

$\underline{\text { Reasons for the Shift in ALP policy }}$

The US commenced withdrawal in 1969. Some have argued that this was the crucial factor in the hardening of Labor's stance on withdrawal, rather than, as has been argued in this article, the change in public opinion and the growth of the AVWM. For instance, Saunders endorses Catley’s argument that “it was the shift in American policy which determined the evolution of ALP policy [on withdrawal from Vietnam]”. However, there is strong evidence tying such factors to both US withdrawal and the shift in ALP policy. According to Webster's New World Dictionary of the Vietnam War, the Tet Offensive "convinced many Americans that the war could not be won, setting in motion the process of eventual U.S. withdrawal and tilting public opinion in favour of ending combat intervention." Former US Secretary of State Henry Kissinger conceded: "Nixon ordered troop reductions because of our domestic situation. The US appetite for withdrawal had become 
insatiable". In a recent book, Jonathan Neale argued that three factors were crucial to the US government's withdrawal: the resistance of the Vietnamese themselves, the protest movement and wider public opposition, and a revolt amongst US troops. There is of course a dialectical interaction between these three, but it could be argued that the first two were the most important, since it is much less likely that the unrest amongst American service personnel would have occurred had the other two factors not come into play. ${ }^{57}$

As was shown earlier in the paper, the ALP responded noticeably to the growth of the AVWM and the increasing resentment towards the war. Although it is undoubtedly the case that the US shift lent greater credibility to Labor's policy, it is likely that a shift on the part of the latter would have occurred even in the absence of any change in US policy. There is also no general trend of convergence between the two policies (even its confused 1966 position of withdrawal went directly against US policy), and nor is there evidence that the shift was about cosying up to the US Government. That it was not a case of the latter was evident in the modification of the ANZUS policy. The rift between the ALP and US foreign policy continued even after the party took power. For instance, when the US resumed bombing of North Vietnam in late-December 1972, Whitlam refused to condemn industrial action against US ships by Australian maritime unions, while one government minister attacked the "maniacs" in command of US policy. Saunders interprets this as a "sign to the peace movement that now it had assumed power the ALP would not renege on or renounce its allies in the peace movement". ${ }^{58}$ This only casts further doubt on Saunders' own claim that American withdrawal was the catalyst for a change in ALP policy. 
Historians' argument that the Liberal Government's decision to withdraw from Vietnam merely followed the direction of Washington's policy ${ }^{59}$ is similarly unconvincing: in fact, the Australian Government was under domestic pressure comparable to that which, in part, led the US Government to withdraw. Vietnam hurt the Liberal Government at the 1969 Federal Election, and perhaps it is no coincidence that not long after the Government announced its intention to commence withdrawal. Saunders concedes that the decision was partly inspired by the Government's desire "to take away the raison d'etre of the protest movement". One Federal Labor MP concurred with this view: "It was the people coming onto the streets...that forced governments as powerful as the Government of the United States to withdraw its troops from Vietnam.”60

Labor MPs were not unaware of the change in public opinion, which leads one to believe that this was an important factor in the policy shift. Thus, whereas Whitlam sought initially to soften Labor's opposition to the war, by 1969 he could inform that year's Federal Conference that: "Today, if anything, Vietnam is an electoral asset for the A.L.P.". Fred Daly recalled: "Whitlam had sniffed the breeze and being pragmatic, changed his attitude on Vietnam. Suddenly, he was making speeches against the war... Whitlam was astute and realised the growing disquiet." Lance Barnard also noted the shift in public sentiment. In contrast to 1966 when a majority supported the war, in 1969 he believed that the mood had "gone full circle...until now there is an atmosphere of disenchantment". ${ }^{61}$

Anti-war activists for their part believed their actions had impacted on Labor. Gibson, for example, argued that the mass movement "compelled the Labor Party to commit itself pretty heavily on the Vietnam War, [and] on conscription...” Chris Gaffney similarly suggested that the ALP's opposition to conscription was a case of 
Labor responding to working class pressure in an effort to both maintain that class's allegiance to capitalism, and to earn its electoral support. Hamel-Green credited student and anti-war organisations' campaigning efforts with bringing about the change in Jim Cairns' attitude towards supporting direct action during the Moratorium. The view that the AVWM played a key role in Labor's policy change is lent support from an unlikely source: at the front line during many of the protests, one repentant police officer declared that "the demonstrators changed Australia's history. It will be a very brave government that ever commits itself and its citizens to a prolonged war or a conflict again...”62

Alas, if this is true, the Howard Coalition Government has proven itself to be very "brave” in its recent engagement of Australia in the US-led unprovoked war on Iraq. As war beckoned in February 2003, the largest demonstrations in Australia's history took place. The failure of these protests to prevent war, compared to the relative successes of the AVWM, perhaps should be the subject of future study.

\section{$\underline{\text { Conclusion }}$}

In his concluding remarks on the relationship between Labor and the AVWM, Saunders writes that throughout the duration of the conflict, "the ALP as a whole was always divided on and ambivalent toward the peace movement.”63 This might be historically accurate as a general statement about Labor and Vietnam. What this overlooks, however, is the major shift from early tacit support for US imperialism in Asia. The policy changes, the election of Labor MPs to Moratorium committees, the espousal of, and sometimes active involvement in, civil disobedience by senior 
figures in the party, the passionate defence of protestors during debates in Parliament

- all these point to a party being swept along by a mass movement, of which it struggled to stay ahead. While this paper has stressed the positive responses to the AVWM by the ALP - motivated as they often might have been by the party's strategic interests - and sometimes neglected the negative ones, this has been necessary to correct an imbalance in some histories of the subject.

Correcting this imbalance was also important because the ALP's response to the AVWM reflects the way in which Labor - a party founded on the promise of reducing the vulnerability of the majority to the vicissitudes of capitalism - can be affected by great social and political convulsions. It can be tentatively proffered that, were convulsions of a comparable kind to be repeated, the party’s origins, its representation of diverse social forces, and the resulting expectations of many of its members and supporters, mean that today's federal Labor Opposition would similarly be affected, even if perhaps not on the same scale. As to whether it could contain and control the upheaval, and how its response would be shaped by the growth of parties to its left such as the Greens, one can only speculate. ${ }^{64}$

\footnotetext{
${ }^{1}$ The author thanks Tom O'Lincoln, John Wanna, and Pat Weller, as well as this journal's two anonymous referees, for helpful comments and suggestions on previous drafts of the paper. Any factual inaccuracies, omissions, or errors are, of course, the sole property of the author.

${ }^{2}$ See A. Lavelle, In the Wilderness: Federal Labor in Opposition, Unpublished PhD Thesis, (Griffith University, 2003), pp. 267-274, for a discussion about the factors shaping the ALP's political direction in Opposition. On the British Labour Party, see T. Cliff \& D. Gluckstein, The Labour Party: A Marxist History, (London: Bookmarks, 1996), p.313. On the Socialist Objective, see I. Turner, In Union is Strength: A History of Trade Unions in Australia, 1788-1978, $2^{\text {nd }}$ Ed, (Melbourne: Nelson, 1978) pp65, 70, $72,73$.

${ }^{3}$ C. Gaffney, "The Socialist Objective", Action, (April 21, 1972), p.5. The term reformist, when applied to the ALP, encompasses both "labourism" and "social democracy", which have subtle differences. See H. Manning, “The ALP and the Union Movement: 'Catch-All' Party or Maintaining
} 
Tradition?”, Australian Journal of Political Science, 27 (1), (March, 1992), pp12-14. Both have a common desire to achieve social justice within existing political and economic structures.

${ }^{4}$ K. Cole, "Unions and the Labor Party", in K. Cole, (Ed) Power, Conflict and Control in Australian Trade Unions, (Ringwood: Pelican, 1982), p.87; Cliff \& Gluckstein, The Labour Party, p.103; J. McClelland, Stirring the Possum: A Political Autobiography, (Ringwood: Penguin, 1988), p.136.

${ }^{5}$ D. Horne, Time of Hope: Australia 1966-72, (Melbourne: Angus \& Robertson, 1980), p.7 (emphasis added). On the global radicalisation, see C. Harman, The Fire Last Time: 1968 and After, (London: Bookmarks, 1988). Z. Cowen, The Fragile Consensus, (University of Sydney, 1977), pp5, 6, 8, 9. ${ }^{6}$ G. Langley, A Decade of Dissent: Vietnam and the Conflict on the Australian Homefront, (North Sydney: Allen \& Unwin, 1992), p. x.

${ }^{7}$ Freudenberg, cited in Langley, A Decade of Dissent, p. x; R. Manne, “The Whitlam Revolution”, in R. Manne, (Ed), The Australian Century: Political Struggle in the Building of a Nation, (Melbourne: Text Publishing, 1999), p.183

${ }^{8}$ Although this paper is about the shifting attitudes to the Vietnam War by the ALP in general, close attention is paid to the response of the FPLP.

${ }^{9}$ This brief history of Australia's early involvement in the war borrows heavily from John Murphy's, Harvest of Fear: a History of Australia's Vietnam War, (St Leonards: Allen \& Unwin, 1993), esp. the Introduction, and Chapters Five and Six; M. Goot \& R. Tiffen, "Public Opinion and the Politics of the Polls", in P. King, (Ed) Australia's Vietnam: Australia in the Second Indo-China War, (Sydney: George Allen \& Unwin, 1983).

${ }^{10}$ See M. Sexton, War for the Asking: Australia's Vietnam Secrets, (Ringwood: Penguin, 1981); R. Kuhn, "The Australian Left, Nationalism and the Vietnam War", Labour History, No.72, May (1997), especially pp174-179.

${ }^{11}$ P. Strangio, Keeper of the Faith: A Biography of Jim Cairns, (Melbourne University Press, 2002), p. 143. Caucus comprises all federal Labor MPs, who generally meet weekly during parliamentary sittings.

${ }^{12}$ Now known as the National Executive, its main task is to deal with federal matters arising between the party's biennial national conferences.

${ }^{13}$ Federal Executive, cited in Commonwealth Parliamentary Debates (CPD), House of

Representatives, (25 March 1965), p.348; Beazley, cited in T. Uren, Straight Left, (Milsons Point: Random House, 1995), p.183.

${ }^{14} C P D$, House of Representatives, (23 March 1965), pp241, 242.

${ }^{15} \mathrm{CPD}$, House of Representatives, (25 March 1965), p.386.

${ }^{16}$ Strangio, Keeper of the Faith, pp143, 144; Calwell, CPD, House of Representatives, (23 March 1965), p.242.

${ }^{17}$ Kuhn, "The Australian Left, Nationalism and the Vietnam War", p.163.

${ }^{18}$ CPD, House of Representatives, (23 March 1965), pp246-250; Strangio, Keeper of the Faith, p.147.

${ }^{19}$ B. Guy, A Life on the Left: A Biography of Clyde Cameron, (Kent Town: Wakefield Press, 1999), p.201.

${ }^{20}$ For example, Strangio, Keeper of the Faith, pp. 147, 148.

${ }^{21} C P D$, House of Representatives, (4 May 1965), p.1102; see also Gordon Bryant, $C P D$, House of Representatives, (19 August 1965), p.259; and Clyde Cameron, CPD, House of Representatives, (21 October 1965), pp2125, 2126.

${ }^{22}$ Calwell, cited in The Australian, 14 April, (1966), p.3; W.J. Hudson, "Problems of Australian Foreign Policy, July-December 1966", Australian Journal of Politics and History, XIII (1), April (1967), pp 3, 4; Moss Cass, cited in P. Ormonde, A Foolish Passionate Man: A Biography of Jim Cairns, (Ringwood: Penguin, 1981), p.87; Calwell, cited in A. Ramsey, "'We Can Now Speak with One Voice"', The Australian, May 13 (1966), p.1; The Age, 18 July (1966), p.5; I. Fitchett, "Benson's Expulsion Final Blow to Labor's Hopes", Sydney Morning Herald, August 30, (1966), p.2; Beazley Snr, cited in The Australian, 15 September (1966), p.9; The Australian, 4 November (1966), p. 1; Whitlam, cited in The Australian, 22 November (1966), p. 1; G. Freudenberg, A Certain Grandeur: Gough Whitlam in Politics, (Melbourne: Sun Books, 1978), p.61.

${ }^{23}$ On the factional background to Calwell's position, see K.C. Beazley, "Federal Labor and the Vietnam Commitment", in P. King, (Ed), Australia's Vietnam: Australia in the Second Indo-China War, (Sydney: George Allen \& Unwin, 1983), pp46-51. For Calwell's hostility to conscription, see C. Kiernan, Calwell: A Personal and Political Biography, (West Melbourne: Nelson, 1978), p.6.

${ }^{24}$ Labor has bettered its 1966 TPPV result in every poll since. See AEC, House of Representatives -

Two Party Preferred Results 1949-2001, http://www.aec.gov.au/_content/when/past/hor2party.htm; J. Bennetts, "Labor's Front Bench", The Age, February 13 (1967); B. Johns, "Leap in the Dark by Labor", 
Sydney Morning Herald, February 9 (1967); Freudenberg, A Certain Grandeur, p. xi; P. Strangio, “Gough and Jim”, Arena Magazine, 40, April-May (1999), p. 42.

${ }^{25}$ For Whitlam's moderating efforts towards the policy, see M. Saunders, "The ALP's Response to the Anti-Vietnam War Movement: 1965-73", Labour History, No.44, (May, 1983), p. 81. Whitlam, quoted respectively in Murphy, Harvest of Fear, p.207, The Age, 24 November (1967), p. 9, and in T. Charlton, Transcript of Interview with the Leader of the Opposition, Mr. E.G. Whitlam, by Tony Charlton, 18 February 1968, p.4; the Higgins by-election protest is reported in the Sydney Morning Herald, 15 February (1968), p.1.

${ }^{26}$ Technically the party's most sovereign body, only at National Conference, which usually meets biennially but more often if needed, can alterations be made to the ALP's Platform, Constitution and Rules. The power of Conference, as well as other extra-parliamentary bodies such as the National Executive, is considerably usurped when Labor wins office, and the autonomy over party policy transfers largely to Cabinet and the FPLP.

${ }^{27}$ Colbourne, cited in P. Nilon, "Protests Aid Our Enemies, Says ALP Man", The Australian, February 25 (1967), p.1; Langley, A Decade of Dissent, p.126; ALP, Official Reports of the $27^{\text {th }}$ Commonwealth Conference and Special Conference, Hotel Australia, Adelaide, 31 July and succeeding days (1967), p.18; Oakes, cited in Saunders, "The ALP's Response to the Anti-Vietnam War Movement", p83. ${ }^{28}$ Beazley, "Federal Labor and the Vietnam Commitment", p.53; C. Harman, The Fire Last Time, p.74. The Tet Offensive by the National Liberation Front and elements of the North Vietnamese Army against the South Vietnamese Army and US forces were timed to coincide with the Lunar New Year Day, and thereby to take the latter by surprise. Although militarily a setback to the resistance forces because of the heavy casualties suffered, the brazen attack on the US embassy and other prominent facilities was a psychological blow to US troops and the American public, who increasingly turned against the war from that point on.

${ }^{29}$ Goot \& Tiffen, "Public Opinion and the Politics of the Polls", p.134; Hamel-Green, “The Resisters", pp. 105-109, 111; Saunders, "The ALP's Response to the Anti-Vietnam War Movement”, p.79; A. Picot, "Vietnam: How We Won Last Time", Socialist Review, 4, Winter (1991), p. 117.

${ }^{30}$ Picot, "Vietnam", pp. 115, 117; Hamel-Green, "The Resisters”, pp. 108, 113; J. Carmody, "Wild Mobs Storm U.S. Consulate, Police Headquarters", The Age, (July 5, 1968), p.1.

${ }^{31}$ J. Darmody, \& K. Hooper, "10 Hurt as Batons Fly on July 4", The Age, July 5, (1969), p.1; HamelGreen, "The Resisters", p. 113; M.J. Saunders, "Trade Unions in Australian and Opposition to Vietnam and Concription: 1965-73", Labour History, 43, November (1982), p.69; J. Hagan, The History of the A.C.T.U., (Melbourne: Longman Cheshire, 1981), p. 276.

${ }^{32}$ Cited in Goot \& Tiffen, "Public Opinion and the Politics of the Polls", p. 135.

${ }^{33}$ Sydney Morning Herald, "The Bloody War", Sydney Morning Herald, April 2 (1969), p.2; R. Strathdee, "An Anzac Tradition Preserved", Sydney Morning Herald, April 25 (1969), p.2.

${ }_{34}$ Beazley, "Federal Labor and the Vietnam Commitment", p.53; Sydney Morning Herald, 2 August (1969), p.1; Whitlam, cited in Sydney Morning Herald, 2 October (1969), p. 11; AEC, Electoral Pocket Book '99, (1999), p. 69; AEC, House of Representatives Elections 1949-1998; Goot \& Tiffen, "Public Opinion and the Politics of the Polls", pp150-155; H. Armfield, "'Negotiations over Withdrawal took 10 Months'", The Age , December 17 (1969), p.1.

${ }^{35}$ The Australian, 17 November (1969), p. 1; Hamel-Green, “The Resisters”, p.106; CPD, Senate,(6 October 1971), p.1188.

${ }^{36}$ R. Harwood, "Nixon Behind Barricades: He Ignores Biggest U.S. Anti-War Protest ever", The Australian, November 17 (1969), p.1; A. Ramsey, "Cairns is Still Anything but a Defeated Man", The Australian, May 1 (1968), p.2. R. McMullin, The Light on the Hill: The Australian Labor Party 18911991, (Melbourne: Oxford University Press, 1991), p. 322; I. Fitchett, "Loss and Gain for Whitlam in Party Voting", Sydney Morning Herald, November 13 (1969), p.8; The Age, 19 December (1970), p.3. The Age, 15 June (1971), p.5; M. Sexton, Illusions of Power: The Fate of a Reform Government, (Sydney: George Allen \& Unwin, 1979), p.41.

${ }^{37}$ Calder, CPD, House of Representatives, (2 September 1970), pp881, 883; K.Randall, "Whitlam Faces Censure: PM Accuses him of Inciting Troops to Mutiny", The Australian, September 25 (1970), p.1; See E.G. Whitlam, Transcript of Press Conference by the Leader of the Opposition, Mr E.G. Whitlam MP, 10.45pm, 23 September (1970). See also Whitlam's qualifying statement in, CPD, House of Representatives, (24 September 1970), p.1600; Saunders, "The ALP's Response to the AntiVietnam War Movement”, p.88.

${ }^{38}$ Oakes, cited in J. Walter, The Leader: A Political Biography of Gough Whitlam, (St Lucia: University of Queensland Press, 1980), p.22; E.G. Whitlam, Address by the Leader of the Opposition, the Hon E.G. Whitlam, Q.C., M.P., to the ALP 1977 National Conference, July 5; emphasis added. 
${ }^{39}$ The Age, "Whitlam's Dilemma", The Age, July 29 (1969), p.7.

${ }^{40}$ B. Catley, "A Resilient Perspective", in J. Playford \& D. Kirsner, Australian Capitalism: Towards a Socialist Critique, (Ringwood: Penguin, 1972), p.342; Saunders, "The ALP's Response to the AntiVietnam War Movement", p.85. The ALP's response to the Moratorium is similarly downplayed in Murphy, Harvest of Fear, p. 253; Kuhn, "The Australian Left, Nationalism and the Vietnam War", p.168.

${ }^{41}$ Based on SMH, 27 February (1970), p.5; CPD, House of Representatives, (14 April 1970), p.1053; CPD, House of Representatives, (18 March 1970), p.529. CPD, House of Representatives, (14 April 1970), p.1056; Saunders, "The ALP's Response to the Anti-Vietnam War Movement", p.85.

${ }^{42}$ Barnard, CPD, House of Representatives, (16 April 1970), p.1233.CPD, House of Representatives, (7 May 1970), p.1843; SMH, 7 May (1970), p.4.

${ }^{43}$ Whitlam, CPD, House of Representatives, (14 April 1970), pp1057, 1059, 1060 (emphasis added); Murphy, Harvest of Fear, p.252; Whitlam, CPD, House of Representatives, (14 April 1970), p.1059.

For examples of the failure to note the shift in Whitlam's rhetoric, see Strangio, Keeper of the Faith, p. 203; Murphy, Harvest of Fear, pp252, 253.

${ }^{44}$ The Australian, 9 May (1970), p.1; B. McKinlay, The ALP: A Short History of the Australian Labor Party, (Richmond: Heinemann \& Drummond, 1981), pp134, 135.

${ }^{45}$ M. MacCallum, "Post Mortem on the Moratorium", The Australian, May 13 (1970), p.4.

${ }^{46}$ Cited in C.A. Hughes, "Australian Political Chronicle, September-December 1970: The Commonwealth", Australian Journal of Politics and History, XVII (I), April (1971), p.100.

${ }^{47}$ Cavanagh, CPD, Senate, (6 May 1970), p.1155; Keefe, cited in A. Barnes, "Keeffe Calls Labor to Lead Revolt", The Age, June 13 (1970), p.8; emphasis added.

${ }^{48}$ J. Cairns, Living with Asia, (Melbourne: Landsdowne Press, 1965), pp.174, 133; Hamel-Green, cited in Langley, A Decade of Dissent, p.135; Strangio, Keeper of the Faith, pp 155, 170, 172, 173, 188, 189.

${ }^{49}$ Saunders, "The ALP's Response to the Anti-Vietnam War Movement", pp. 86, 87, 91.

${ }^{50}$ Saunders, "The ALP's Response to the Anti-Vietnam War Movement", p. 86; The Australian, 7 August (1970), p.1; 16 September (1970); 19 September (1970), pp.1, 5.

${ }^{51}$ Langley, A Decade of Dissent, p.126; Barnard, cited in J. Stubbs, "Viet Remark by Barnard Annoys Party", The Australian, May 30 (1967), p.1; Saunders, "The ALP's Response to the Anti-Vietnam War Movement”, p. 90.

${ }^{52}$ Cliff, \& Gluckstein, The Labour Party, pp 89, 90; Murphy, Harvest of Fear, pp. 253, 210; C. Gaffney, “The Socialist Objective”, Action, (21 April, 1972), p.5.

53 J. Cairns, Oil in Troubled Waters, (Camberwell: Widescope, 1976), p.23; Melbourne Sun, cited in I. Dowsing, Jim Cairns M.H.R., (Blackburn: Acacia Press, 1971), p.138; P. Strangio, Keeper of the Faith, p. 170.

${ }^{54}$ Cited in The Age, (16 December, 1970), p. 9; emphasis added.

${ }^{55} \mathrm{ALP}$, Platform, Constitution and Rules as Approved by the $28^{\text {th }}$ Commonwealth Conference, Melbourne, August (1969), p.42; ALP, Platform, Constitution and Rules as Approved by the $29^{\text {th }}$ Commonwealth Conference, Launceston, August (1971), p.41; J. Hurst, "Labor Deletes Seato from Platform", The Australian, June 18 (1971), p.5; Cairns, cited in Australian Left Review (1971) "Jim Cairns and Bill Hartley - An Interview", Australian Left Review, No. 30, May (1971), p. 10; Whitlam, cited in The Age, 22 November (1967), p.3 (emphasis added).

${ }^{56}$ Quoted in ALP, Minutes of the $29^{\text {th }}$ Commonwealth Conference of the Australian Labor Party, Launceston, June (1971), pp36, 37; K. Randall, "Labor Rejects Call for Abolition of Asio", The Australian, June 25 (1971), p.3.

${ }^{57}$ For reports on the US pull-out, see R. Macartney, "25,000 May Just be the Start", The Age, June 10 (1969), p.1; The Age (1969) "Facing the Facts", The Age, July 17 (1969), p.7; Saunders, "The ALP's Response to the Anti-Vietnam War Movement", p.84; and Catley, "A Resilient Perspective", p.341; M. Leepson \& H. Hannaford, Webster's New World Dictionary of the Vietnam War, (New York:

Macmillan, 1999), p.392; Kissinger, cited in Socialist Worker, 5 October (2001), p.5; J. Neale, The American War: Vietnam 1960-75, (London: Bookmarks, 2000).

${ }^{58}$ Minister for Labour Clyde Cameron, cited in Saunders, "The ALP's Response to the Anti-Vietnam War Movement”, p.89; Saunders, p.89.

${ }^{59}$ Edwards and, independently, Pemberton cited in Strangio, Keeper of the Faith, p.212 (footnote 13, p.420).

${ }^{60}$ H. Armfield, "First Troops Home by mid-70': 'Negotiations over Withdrawal took 10 Months'", The Age , December 17 (1969), p.1; Saunders, cited in Strangio, Keeper of the Faith, p.420 (footnote 13); Labor MP Keith Johnson, CPD, House of Representatives, (30 November 1976), p. 3001. 
${ }^{61}$ Whitlam, cited in D. Solomon, "'We Will Bring Troops Home"', The Australian, August 2 (1969), p.2; Daley, cited in Langley, A Decade of Dissent, p. 126; Barnard, CPD, House of Representatives, (24 September 1969), p.1829.

${ }^{62}$ R. Gibson, "Communist Activity and Labor Party Change", Australian Left Review, 31, July (1971), pp77, 78; emphasis in original; C. Gaffney, "The Socialist Objective”, Action, (21 April, 1972), p.5; Hamel-Green, and retired police office, cited in Langley, A Decade of Dissent, pp.135, 221.

${ }^{63}$ Saunders, "The ALP's Response to the Anti-Vietnam War Movement", p. 91.

${ }^{64}$ For a brief discussion of this interesting question, see A. Lavelle, "The ALP and Class Struggle: a Case Study of the Whitlam Labor Opposition's (1967-72) Response to Union Unrest", Refereed Paper Presented to the $50^{\text {th }}$ Anniversary Conference of the Australasian Political Studies Association, Canberra, October 2-4, 2002, pp23, 24. 